\title{
Adult-Born Hippocampal Neurons Are More Numerous, Faster Maturing, and More Involved in Behavior in Rats than in Mice
}

\author{
Jason S. Snyder, Jessica S. Choe, Meredith A. Clifford, Sara I. Jeurling, Patrick Hurley, Ashly Brown, J. Frances Kamhi, \\ and Heather A. Cameron \\ Unit on Neuroplasticity, National Institute of Mental Health, National Institutes of Health, Bethesda, Maryland 20892
}

\begin{abstract}
Neurons are born throughout adulthood in the hippocampus and show enhanced plasticity compared with mature neurons. However, there are conflicting reports on whether or not young neurons contribute to performance in behavioral tasks, and there is no clear relationship between the timing of maturation of young neurons and the duration of neurogenesis reduction in studies showing behavioral deficits. We asked whether these discrepancies could reflect differences in the properties of young neurons in mice and rats. We report that young neurons in adult rats show a mature neuronal marker profile and activity-induced immediate early gene expression 1-2 weeks earlier than those in mice. They are also twice as likely to escape cell death, and are 10 times more likely to be recruited into learning circuits. This comparison holds true in two different strains of mice, both of which show high rates of neurogenesis relative to other background strains. Differences in adult neurogenesis are not limited to the hippocampus, as the density of new neocortical neurons was 5 times greater in rats than in mice. Finally, in a test of function, we find that the contribution of young neurons to fear memory is much greater in rats than in mice. These results reveal substantial differences in new neuron plasticity and function between these two commonly studied rodent species.
\end{abstract}

\section{Introduction}

Adult neurogenesis, the birth of neurons in the adult animal, has been observed in the dentate gyrus of mice (Kempermann et al., 1997b), rats (Cameron et al., 1993), macaques (Gould et al., 2001), and humans (Eriksson et al., 1998) and is regulated quite similarly across species. For example, stress decreases granule cell precursor proliferation in mice, rats, and marmosets, while antidepressant treatments increase cell proliferation in all tested species (Malberg et al., 2000; Mirescu and Gould, 2006; Sahay and Hen, 2007). The general similarity in the regulation of neurogenesis across species has led to the tacit assumption that findings in one mammalian species can be applied to others, particularly among rodents. Recently, however, detailed studies of the function of adult neurogenesis have produced divergent views of how new neurons contribute to hippocampal physiology and behavior. A number of studies have suggested that new granule neurons contribute electrophysiologically and behaviorally to hippocampal function by 4 weeks of age (Snyder et al., 2005; Winocur et al., 2006; Wojtowicz et al., 2008) and, in several cases, as young as

\footnotetext{
Received April 13, 2009; revised Sept. 8, 2009; accepted Sept. 30, 2009.

This research was supported by the Intramural Program of the National Institutes of Health, National Institute of Mental Health, Z01-MH002784 (H.A.C.). We thank Sarah Kellner, Andrea Moderi, and Kaitlin Sanzone for assistance with histological analyses and Anastasia Sowers and James Mitchell for assistance with the irradiation procedures.

Correspondence should be addressed to Jason S. Snyder, Unit on Neuroplasticity, National Institute of Mental Health, National Institutes of Health, Building 35/3C911, MSC3718, Bethesda, MD 20892. E-mail: snyderjason@ mail.nih.gov.

DOI:10.1523/JNEUROSCI.1768-09.2009

Copyright $\odot 2009$ Society for Neuroscience $\quad 0270-6474 / 09 / 2914484-12 \$ 15.00 / 0$
}

$\sim 2-3$ weeks of age (Shors et al., 2001; Snyder et al., 2001; Shors et al., 2002; Madsen et al., 2003; Schmidt-Hieber et al., 2004; Bruel-Jungerman et al., 2005). In contrast, several electrophysiological studies (van Praag et al., 2002; Espósito et al., 2005; Ge et al., 2006; Ge et al., 2007), as well as some morphological (Zhao et al., 2006; Toni et al., 2007) and behavioral (Jessberger and Kempermann, 2003; Kee et al., 2007) experiments, suggest that new neurons are minimally functional at this age, and would be unlikely to be able to contribute to behavior until at least $6-8$ weeks of age. Although species has not been considered to be an important factor in these studies, those suggesting early functionality of new neurons were done in rats, whereas those showing more delayed function of new neurons were performed in mice. Thus, the lack of correspondence among findings could be explained if new neurons mature faster and/or make a greater contribution to hippocampal function in rats than in mice.

We designed the current study to directly compare the magnitude, maturation, activity pattern, and behavioral requirement of adult-born granule cells in mice and rats. We find that granule cell maturation in mice lags significantly behind that in rats as seen both with neuronal markers and immediate-early gene expression. The time course of cell death is similar across species, but a much greater proportion of new cells die in mice. The cells that do survive in mice are less likely to be activated by physiological stimuli than young neurons in rats. Finally, inhibition of neurogenesis produces deficits in contextual fear conditioning behavior in rats but not mice. Collectively, these large differences between mice and rats reconcile 
many of the inconsistencies in the observed functionality of new neurons in the hippocampus.

\section{Materials and Methods}

Animals and treatment groups. A total of 145 adult male mice and 141 adult male rats were used in the following experiments. C57BL/6 mice (National Cancer Institute Animal Production Area, Frederick, MD) and Sprague Dawley rats (Charles River), common strains for studies of adult neurogenesis, were used in all experiments except one, which used CD1 mice (Charles River) and Long-Evans rats (Charles River) to extend the results to additional strains. All experiments began when the animals were 8-9 weeks old and had been acclimated to the animal facility for at least 1 week. Mice were housed 2-4 per cage, and rats were housed 2 per cage, in different rooms within the same animal facility. All animals had ad libitum availability of food and water and were subjected to a $12 \mathrm{~h}$ light/dark schedule with lights on from 6:00 A.M. to 6:00 P.M. For all experiments, bromodeoxyuridine (BrdU) was given intraperitoneally at $200 \mathrm{mg} / \mathrm{kg}$ per injection $(10 \mathrm{mg} / \mathrm{ml}$ in saline with $0.007 \mathrm{~N} \mathrm{NaOH})$.

Several slightly different regimens were used for different timelines. To measure immediate-early gene response to maximal stimulation, rats ( $n=3-5$ per group, 26 total) were given a single injection of BrdU, mice ( $n=2-5$ per time point, 21 total) were given 2 injections of BrdU $8 \mathrm{~h}$ apart to compensate for lower numbers of $\mathrm{BrdU}^{+}$cells, and all animals were given kainic acid to induce seizures (see below) 90 min before being perfused 7, 11, 14, 21, 28, or $70 \mathrm{~d}$ after BrdU injection. To measure the immediate early gene (IEG) response to behavioral activity, rats $(n=$ 4-6 per time point, 23 total) and mice ( $n=2-4$ per time point, 16 total) were given 2 daily BrdU injections ( $8 \mathrm{~h}$ apart) for $3 \mathrm{~d}$ because of the relatively low numbers of $\mathrm{IEG}^{+}$cells expected after water maze training (Snyder et al., 2009a), and all animals were trained in the water maze (see below) $2 \mathrm{~h}$ before perfusion 7, 14, 21, 28, or $70 \mathrm{~d}$ after BrdU injection. An additional set of mice was given a single injection of BrdU and perfused 1 , 2, 3, 4, or 10 weeks later ( $n=4$ per time point, 20 total) with no treatment the day of perfusion for $\mathrm{BrdU}^{+}$cell counts and neuronal marker expression. These mice were compared with rats in the seizure group above, which were also given a single $\mathrm{BrdU}$ injection. $\mathrm{CD} 1$ mice $(n=8$ per time point) and Long-Evans rats ( $n=6$ per time point) were given a single injection of BrdU and perfused 1, 2, 3, or 4 weeks later to determine rates and time courses of neurogenesis in these strains.

For the irradiation-behavior experiment, mice and rats were irradiated at 8 weeks of age to inhibit adult neurogenesis. Animals were tested for contextual fear conditioning, a hippocampal-dependent test shown to require young neurons in both rats and mice (Saxe et al., 2006; Winocur et al., 2006) 3 (rats only), 4 , or 8 weeks later ( $n=10-14$ per species per time point). Following behavioral testing, animals were perfused for histological confirmation of loss of neurogenesis.

Seizures. Kainic acid (Tocris Bioscience) was used to induce seizures in mice (35 mg/kg; i.p.) and rats ( $15 \mathrm{mg} / \mathrm{kg}$; i.p.) to activate the dentate gyrus and induce IEG expression. Though IEGs such as zif268 and Fos are upregulated in very few granule cells under physiological conditions including novelty exposure or learning, virtually all granule cells upregulate IEGs in response to electrical activity during seizures (Cole et al., 1990). Therefore, seizure-induced IEG expression provides a measure of whether new neurons are functionally integrated into the circuitry (Jessberger and Kempermann, 2003; Snyder et al., 2009b). Initial seizure activity consisted of episodes of stillness, chewing, and head bobbing. Subsequently, stage 5 seizures developed, which were behaviorally characterized by episodes of rearing and falling (Racine, 1972). Stage 5 seizures began 20-30 min after injection in mice and 60-90 min after injection in rats. Seizures were stopped by injection of the GABA agonist sodium pentobarbital ( $50 \mathrm{mg} / \mathrm{kg}$; i.p.) $30 \mathrm{~min}$ after the onset of stage 5 seizure activity. Animals were perfused $60 \mathrm{~min}$ later (i.e., $90 \mathrm{~min}$ after stage 5 seizure onset). The timing of stimulation and perfusion therefore followed a schedule similar to that in the water maze experiment (see below).

Water maze training. Mice and rats were handled during the week before training to minimize stress and anxiety during training. The water maze was a circular pool, $140 \mathrm{~cm}$ in diameter, filled with water. A circular platform, $10 \mathrm{~cm}$ in diameter, provided escape but was hidden from the animal by being slightly submerged under water made opaque by the addition of nontoxic white tempera paint (Dick Blick Art Materials). A trial began when the animal was placed in the pool, facing the pool wall, and ended when the animal mounted the platform. If the animal failed to find the platform within $60 \mathrm{~s}$, it was placed on the platform by the experimenter. All animals were left on the platform for $10 \mathrm{~s}$ after each trial and were returned to their cage for a 2-3 min intertrial interval. During all training, the experimenter remained hidden behind a curtain during the trials. Animals were released from the N, S, E, and W points of the pool in a counterbalanced manner such that the frequency of releases from a given point was distributed equally across trials. To ensure that animals learned the spatial task efficiently in one day, they received nonspatial and then simple spatial pretraining before the final training day. Rats received both nonspatial pretraining and simple spatial pretraining on the day before spatial training; mice were pretrained spatially $1 \mathrm{~d}$ prior and nonspatially $4 \mathrm{~d}$ before spatial training. Nonspatial pretraining consisted of 6 trials with the platform located in the center of the pool, a cue (black and white striped cylinder) hanging directly over the platform, and extra-maze cues minimized with black curtains surrounding the pool. During spatial pretraining mice received 6 trials with the platform in the center of the NW quadrant of the pool. The platform was no longer cued locally. Instead, black curtains surrounded the pool and a single white board hanging against one curtain provided a simple spatial reference for locating the platform. For spatial training on the final day, the platform remained in the NW quadrant and all curtains but one were removed, exposing distal spatial cues located on the walls of the room. Animals received 6 spatial training trials and were killed $2 \mathrm{~h}$ after the first trial ( $\sim 100 \mathrm{~min}$ after the last trial). Latency to find the platform and mean proximity to the platform were calculated for each trial using Ethovision software (Noldus). For the proximity measure (Gallagher et al., 1993), the distance of the animal from the platform location was calculated at $0.1 \mathrm{~s}$ intervals. The mean of these values was then calculated for each trial. An animal that searches in the correct area of the pool will have a low mean distance value, providing a measure of spatial bias for the platform location that should decrease across trials if animals learn the location of the platform. In addition, if the search pattern is spatially selective, the difference between the mean distance from the platform location and from a hypothetical "platform" location at the opposite side of the pool should increase across blocks.

Irradiation. Eight-week-old mice and rats were subjected to $10 \mathrm{~Gy}$ irradiation on 2 consecutive days to inhibit adult neurogenesis (Snyder et al., 2005). Before irradiation, animals were anesthetized with sodium pentobarbital $(50 \mathrm{mg} / \mathrm{kg}$; i.p.). Mice were placed in a Plexiglas jig designed specifically to position the animal for brain irradiation, while shielding the rest of animal's body with lead. Radiation was delivered with a Therapax DXT300 x-ray irradiator (Precision Xray) using $2.0 \mathrm{~mm}$ $\mathrm{Al}$ filtration $(300 \mathrm{KVp})$ at a dose rate of $2.28 \mathrm{~Gy} / \mathrm{min}$. Rats were irradiated with a cobalt-60 unit (Eldorado 8, Atomic Energy Canada Limited) using a dose rate of $1.54 \mathrm{~Gy} / \mathrm{min}$. The cobalt-60 beam was collimated to a narrow rectangular field directed over the head of the animal. Lead blocks placed on a Plexiglas platform above the rats were used to further shield extra-hippocampal brain regions, the oral cavity and neck.

Contextual fear conditioning. Irradiated and sham-irradiated mice and rats were handled for $3 \mathrm{~d}$ during the week before behavioral testing. The testing environment consisted of two conditioning chambers (Coulbourn Instruments) placed in the center of a room, $\sim 2$ feet apart, and visually separated by an opaque divider. The chambers had clear Plexiglas walls to give visual access to a contextually rich environment consisting of numerous proximal and distal room cues. For training, animals were placed in the chamber for a total of $12 \mathrm{~min}$. After $5 \mathrm{~min}$ of exploration, 7 tone-shock pairings were delivered. The tone was $75 \mathrm{~dB}, 2000 \mathrm{~Hz}, 20 \mathrm{~s}$ in duration and coterminated with a $1 \mathrm{~s}$ scrambled footshock unconditioned stimulus ( $1.0 \mathrm{~mA}$ for rats, $0.6 \mathrm{~mA}$ for mice; different sized grid floors for the two species). One-minute intervals separated the unconditioned stimuli. The chambers were cleaned in between trials with a dilute cleaning solution of $2 \%$ Simple Green (McMaster-Carr) in water. To test contextual fear memory, animals were placed in the conditioning context $24 \mathrm{~h}$ later and the total duration of freezing behavior was monitored for 5 min. To test the specificity of the memory deficit, animals were placed in a distinct context $3 \mathrm{~h}$ later, and freezing to a $1 \mathrm{~min}$ presentation of the 
tone was monitored. Freezing was defined as the absence of all movement save respiration and was analyzed using Freezeview software (Coulbourn Instruments).

Histological methods. In all experiments, animals were perfused with $4 \%$ paraformaldehyde in phosphate buffered saline (PBS; $\mathrm{pH} 7.4$ ). Brains remained in fixative overnight after which they were either transferred to $20 \%$ sucrose for at least $24 \mathrm{~h}$ before being processed (mouse BrdU timeline experiment) or transferred to a $10 \%$ glycerol solution for $24 \mathrm{~h}$ and then a $20 \%$ glycerol solution for $48 \mathrm{~h}$ before being processed (all other experiments). Brains were sectioned coronally on a freezing microtome at a $40 \mu \mathrm{m}$ thickness. For stereological BrdU counts, 1 in 12 series of sections throughout the entire dentate gyrus were mounted onto slides, heated in citric acid $(0.1 \mathrm{M}, \mathrm{pH} 6.0)$ for $10 \mathrm{~min}$ for antigen retrieval, permeabilized with trypsin for $10 \mathrm{~min}$, and denatured in $2 \mathrm{~N} \mathrm{HCl}$ for 30 min. Sections were then incubated with mouse anti-BrdU antibody (1: 100; BD Biosciences) at $4^{\circ} \mathrm{C}$ overnight followed by biotinylated goat anti-mouse IgG (1:200; Sigma) at room temperature for $1 \mathrm{~h}$. BrdU was then visualized using an avidin-biotin-horseradish peroxidase kit (Vector Laboratories) and cobalt-enhanced DAB (Sigma Fast tablets). Slides were then counterstained with cresyl violet acetate and coverslipped with Permount.

The maturation and activation marker expression profile of BrdU+ cells was determined using immunohistochemical double or triple labeling with fluorescent detection. Free-floating sections were treated with 2 $\mathrm{N} \mathrm{HCl}$ for $1 \mathrm{~h}$ and subsequently incubated simultaneously in two primary antibodies, diluted in PBS containing $0.5 \%$ Triton-X and 3\% donkey serum, for $1-3 \mathrm{~d}$ at $4^{\circ} \mathrm{C}$. Primary antibodies used were as follows: rat anti-BrdU antibody at 1:2500 (Accurate, OBT0030), mouse anti-BrdU antibody at 1:200 (BD Biosciences, 347580), goat anti-doublecortin (antiDCX) at 1:200 (Santa Cruz Biotechnology, sc-8066), rat anti-polysialic acid (anti-PSA)-neural cell adhesion molecule (anti-PSA-NCAM) at 1:400 (BD Biosciences, CD56, 556325), mouse anti-neuronal-specific nuclear protein (anti-NeuN) at 1:250 (Millipore Bioscience Research Reagents, MAB377), rabbit anti-calbindin (anti-CB) at 1:5000 (Swant, CB38), mouse anti-proliferating cell nuclear antigen (anti-PCNA) at 1:20 000 (Santa Cruz Biotechnology, sc-56), rabbit anti-zif268 at 1:1000 (Santa Cruz Biotechnology, sc-189), and rabbit anti-Fos at 1:10,000 (Calbiochem, PC38). Visualization was performed with donkey anti-rat Alexa488, donkey anti-goat Alexa555, donkey anti-mouse Alexa555, donkey anti-mouse Alexa633, donkey anti-rabbit Alexa555, and donkey anti-rabbit Alexa647 antibodies (Invitrogen), all at 1:250 dilutions in PBS for $90 \mathrm{~min}$ at room temperature. Exceptions were PSA-NCAM staining, which was performed before $\mathrm{HCl}$ treatment and BrdU staining and used goat serum and goat anti-rat IgM Alexa594 secondary antibody, and PCNA staining, which included $10 \mathrm{~min}$ incubation in citric acid at $90^{\circ} \mathrm{C}$ before $\mathrm{HCl}$ treatment for antigen retrieval. Sections were mounted onto slides and coverslipped with Prolong Gold (Invitrogen).

Histological data analysis. Stereological counts of DAB-labeled BrdU ${ }^{+}$ cells were performed using a $40 \times$ objective on a 1 in 12 series of sections through the entire dentate gyrus. All $\mathrm{BrdU}^{+}$cells located in the granule cell layer or within $20 \mu \mathrm{m}$ of the granule cell layer (in the subgranular zone) were counted, and the sum was multiplied by 12 to obtain an estimate of the total (bilateral) number of $\mathrm{BrdU}^{+}$cells per animal.

Cell density measurements were obtained by dividing the number of $\mathrm{BrdU}^{+}$cells in each animal by the total volume of the granule cell layer in the analyzed sections. To obtain volume measurements, the granule cell layer was traced using Stereoinvestigator software (Microbrightfield) and a $4 \times$ objective, and the resulting cross-sectional area was multiplied by the section thickness $(40 \mu \mathrm{m})$.

Marker expression was examined in $\sim 25 \mathrm{BrdU}^{+}$cells per animal, sampled from the entire mediolateral and infrapyramidal-suprapyramidal regions of sections from the dorsal dentate gyrus, using a $60 \times$ oilimmersion lens (numerical aperture, 1.25). Expression of DCX, PSANCAM, and CB was verified qualitatively by confocal microscopy. To objectively quantify graded expression of Fos, zif268, and NeuN in $\mathrm{BrdU}^{+}$cells, fluorescence intensity was measured and compared to background levels within each field, as previously described (Snyder et al., $2009 b)$. For the water maze experiment, $\mathrm{BrdU}^{+}$cells were counted under epifluorescence (100-200 per mouse, 50-100 per rat), and potential
$\mathrm{BrdU}^{+} / \mathrm{IEG}^{+}$cells were verified by confocal microscopy as in the seizure animals. For all markers, expression levels are presented as the percentage of $\mathrm{BrdU}^{+}$cells staining positively for a given marker.

New neocortical and striatal neurons were quantified in animals from the water maze-IEG experiment. Sections were taken from $\sim 0.0$ to 0.5 $\mathrm{mm}$ relative to Bregma in mice and -0.8 to $1.6 \mathrm{~mm}$ in rats. To quantify neocortical neurogenesis the deep aspect of the neocortex $(\sim 225 \mu \mathrm{m}$ wide) was examined under epifluorescence using a $60 \times$ oil-immersion lens. All potential BrdU ${ }^{+} / \mathrm{NeuN}^{+}$cells were scanned on a confocal microscope at $0.5-1.0 \mu \mathrm{m}$ intervals to confirm double-labeling (Dayer et al., 2005). The number of neocortical BrdU ${ }^{+}$cells examined ranged from 112 to 170 per mouse and from 128 to 350 per rat. Adult-born striatal neurons were similarly counted within a $225-\mu \mathrm{m}$-wide band of the dorsomedial striatum, near the subventricular zone, as has been previously described (Dayer et al., 2005). The number of striatal BrdU ${ }^{+}$cells examined ranged from 106 to 135 per mouse and from 94 to 163 per rat, and potential double-labeling for BrdU and NeuN was confirmed in all cells via confocal microscopy as in the neocortex.

Statistical comparisons were performed with one-way or two-way ANOVA with significance set at $p<0.05$. Bonferroni post hoc tests were used unless indicated otherwise.

\section{Results}

\section{Mature pattern of neuronal markers appears more quickly in} rat granule cells than mouse granule cells

All neuronal markers stained strongly and specifically in both mice and rats. DCX is expressed specifically by young neurons and neuronal precursors and plays a role in axon and dendrite outgrowth and branching (Brown et al., 2003; Kerjan et al., 2009; Tint et al., 2009). DCX expression was observed in nearly all 1 -week-old $\mathrm{BrdU}^{+}$cells in both species $(89 \pm 2 \%$ in mice and $89 \pm 5 \%$ in rats) (Fig. $1 A, B$ ). In both species, the percentage of DCX-expressing cells dropped to zero, but the time course of this decrease was significantly different between species (Fig. 1B). Significantly more $\mathrm{BrdU}^{+}$cells were $\mathrm{DCX}^{+}$in mice than in rats at 2,3 , and 4 weeks, a difference that was especially pronounced at 3 weeks, when $90 \pm 7 \%$ of BrdU ${ }^{+}$cells express DCX in mice, compared with only $18 \pm 7 \%$ of cells in rats.

The early neuronal marker PSA-NCAM was expressed in a high proportion of 1 -week-old $\mathrm{BrdU}^{+}$cells (Fig. $1 D, E$ ), nearly identical to the proportion expressing DCX. As with DCX expression, mice and rats showed significantly different time courses for loss of PSA-NCAM (Fig. 1E). Rats showed no significant difference between PSA-NCAM expression and DCX expression between 1 and 4 weeks after BrdU injection $\left(F_{(1,32)}=0.76, p=0.39\right.$ for main effect of marker, $F_{(4,32)}=0.59, p=0.67$ for interaction between marker and cell age). Mice, however, showed significantly different expression of PSA-NCAM versus $\operatorname{DCX}\left(F_{(1,25)}=51\right.$, $p<0.0001$ for main effect of marker and $F_{(4,25)}=17, p<0.0001$ for marker $\times$ cell age interaction), with post hoc analyses showing significantly less PSA-NCAM expression than DCX expression 3 weeks and 4 weeks after BrdU injection $(p<0.001$ and $p<0.01$, respectively).

Calbindin expression was low in both species 1 week after BrdU injection $(8 \pm 5 \%$ and $9 \pm 3 \%$ in mice and rats, respectively). Between 1 and 3 weeks, the proportion of $\mathrm{CB}^{+}$cells increased, reaching a peak of $60 \pm 7 \%$ and $56 \pm 4 \%$ in mice and rats, respectively. Even at the longest time points examined, $\sim 40 \%$ of $\mathrm{BrdU}^{+}$cells in the granule cell layer did not express $\mathrm{CB}$ (Fig. $1 F, G$ ), indicating that while $\mathrm{CB}$ expression reflects some level of maturity, lack of $\mathrm{CB}$ expression provides no information about cell maturity. Mice and rats showed no significant differences in the expression of calbindin at any time point. Since calbindin's calcium binding ability plays an important role in mossy fiber-CA3 synapses (Blatow et al., 2003), this lack of spe- 

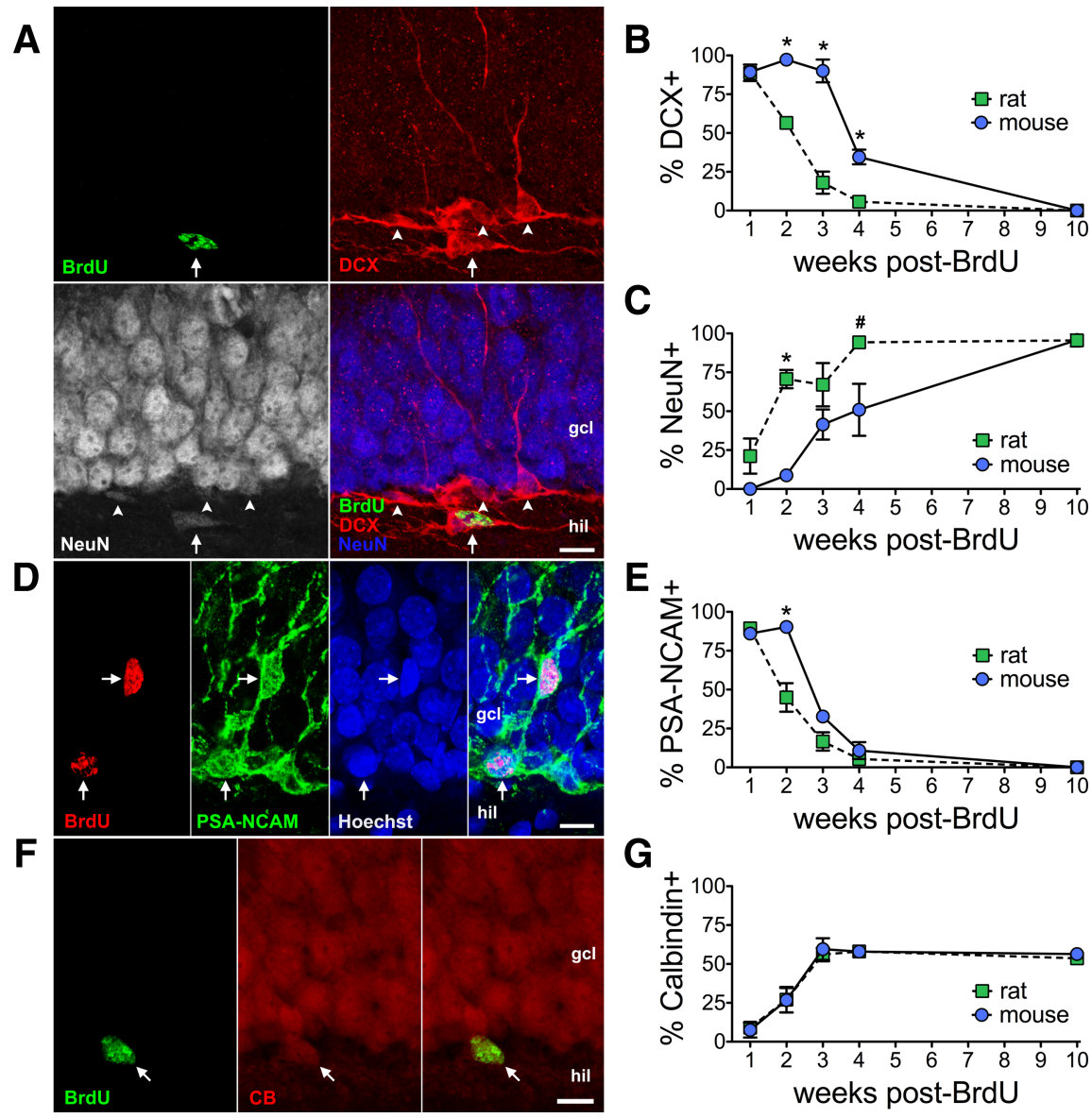

C

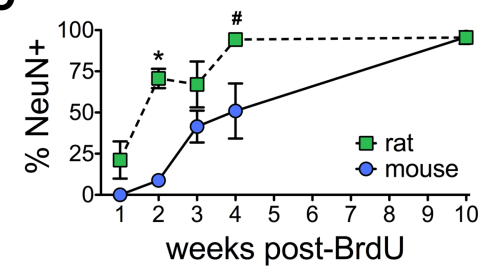

E

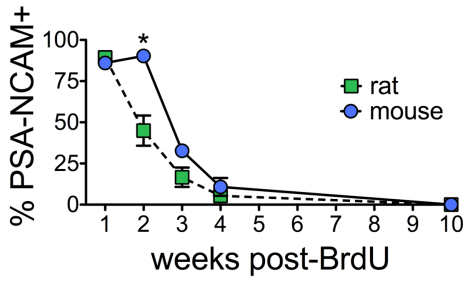

G

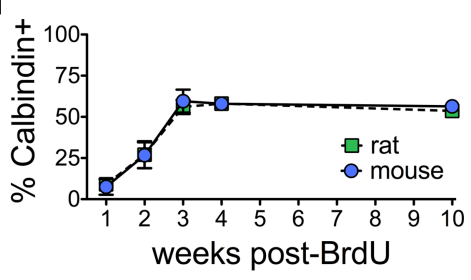

Figure 1. Different time courses of neuronal marker expression in mice and rats. $A$, Photo showing positive immunostaining for the early neuronal marker $D C X$ and immunostaining for the late neuronal marker NeuN in several mouse granule cells (arrowheads), including a 1-week-old BrdU ${ }^{+}$cell with weak NeuN staining categorized as negative (arrow). $\boldsymbol{B}$, The proportion of $\mathrm{BrdU}^{+}$ cells double-labeled with $D C X$ decreased more rapidly in rats than in mice $\left(F_{(1,31)}=116, p<0.0001\right.$ for main effect of species, $F_{(4,31)}=161, p<0.0001$ for cell age, and $F_{(4,31)}=26, p<0.0001$ for their interaction). $C$, The onset of strong NeuN expression was delayed in mice relative to rats $\left(F_{(1,30)}=23, p<0.0001\right.$ for main effect of species, $F_{(4,30)}=18, p<0.0001$ for main effect of cell age, and $F_{(4,30)}=2.7, p<0.05$ for their interaction). $\boldsymbol{D}$, Photo showing immunostaining for the early neuronal marker PSA-NCAM in two 1-week-old BrdU ${ }^{+}$cells in a rat (arrows). $E$, Immunostaining for PSA-NCAM was prolonged in mice compared with rats $\left(F_{(1,26)}=18, p<0.001\right.$ for main effect of species, $F_{(4,26)}=131, p<0.0001$ for main effect of cell age, and $F_{(4,26)}=8.5$, $p<0.001$ for their interaction). $\boldsymbol{F}$, Photo showing immunostaining for the late neuronal marker calbindin in a 4-week-old BrdU ${ }^{+}$ cell (arrow) in a rat. G, The onset of expression of calbindin was equivalent in mice and rats but only reached $60 \%$ in both species. All scale bars, $10 \mu \mathrm{m}$; gcl, granule cell layer; hil, hilus; ${ }^{\#} p<0.05,{ }^{*} p<0.001$ versus mouse at the same time point, in post hoc tests following two-way (species $\times$ cell age) ANOVA. In this figure and those that follow, symbols represent mean \pm SEM and short error bars on some data points are hidden by symbols.

cies difference might reflect similar timing of functional output from granule cells.

NeuN is the most widely used antibody marker of mature neurons, recently identified as Fox-3, an RNA splicing regulator (Kim et al., 2009b). NeuN staining appeared more graded than staining for the other neuronal markers. Therefore, instead of making qualitative judgments of positive staining, we measured the fluorescence intensity of NeuN staining in each $\mathrm{BrdU}^{+}$cell. Using a low criterion, i.e., counting weakly positive ( $\geq 2 \times$ background) NeuN staining, we found that nearly all 1 -week-old $\mathrm{BrdU}^{+}$cells expressed NeuN in both mice and rats (supplemental Fig. 1, available at www.jneurosci.org as supplemental material). This weak NeuN expression was specific, since cells that did not have NeuN expression greater than background levels could be found nearby in the hilus. This early onset of NeuN expression is consistent with findings of Brandt et al. (2003) but inconsistent with the time course of Brown et al. (2003), which showed $\geq 80 \%$ of cells in rats doublelabeled only in cells $\geq 30 \mathrm{~d}$ old. With a more restrictive cutoff $(\geq 5 \times$ background), the proportion of $\mathrm{NeuN}^{+}$cells increased gradually over time (Fig. $1 C$ ), giving a curve in rats similar to that of Brown et al. (2003). Using this criterion, the time course of this increase was significantly different between species, with rats having a greater proportion of strongly $\mathrm{NeuN}^{+}$cells at 2 and 4 weeks after BrdU injection.

\section{Survival rate of new granule cells is higher in rats than mice}

The total number of $\mathrm{BrdU}^{+}$cells in the dentate gyrus, based on stereological counts, was three times higher in rats than in mice at the 1 week time point (Fig. 2A). This difference is unlikely to reflect differences in BrdU uptake or kinetics, as previous studies have shown that the dose used here is sufficient to label all S-phase cells in both species and to dilute out of continuously dividing cells at the same rate (Cameron and McKay, 2001; Dayer et al., 2003; Mandyam et al., 2007). Since rats have three times as many granule cells as mice (West and Andersen, 1980), the amount of initial cell production relative to the entire granule cell population appears to be equivalent in the two species.

Mice and rats both showed significant loss of $\mathrm{BrdU}^{+}$cells between 1 and 10 weeks after BrdU injection (Fig. 2A), as previously described (Brandt et al., 2003; Dayer et al., 2003; Kempermann et al., 2003). Despite the large difference in the number of $\mathrm{BrdU}^{+}$cells between the two species, linear regression analysis showed that the slopes of the regression lines were not significantly different $(p=0.25 ; 101 \pm 18$ cells/d in mice versus $157 \pm 40$ cells/d in rats), indicating that rats and mice lost the same absolute number of cells per day. Calculated as a percentage of the number of $\mathrm{BrdU}^{+}$cells at 1 week (Fig. $2 \mathrm{~B}$ ), mice and rats showed significantly different $\mathrm{BrdU}^{+}$cell loss over the period between 1 week and 4 weeks. Proportional cell loss was similar in the two species from 1 week to 2 weeks after BrdU injection, after which mice showed significantly greater cell loss, retaining only $30 \%$ of $\mathrm{BrdU}^{+}$cells by 4 weeks, compared with $62 \%$ of $\mathrm{BrdU}^{+}$cells in rats. There was no significant loss of cells after 4 weeks in either species. Expressed relative to granule cell layer volume, the density of $\mathrm{BrdU}^{+}$cells was equivalent in rats and mice at 1 week after BrdU injection (Fig. $2 C$ ), again suggesting that initial production of new neurons, relative to the existing population, is similar in the two species. However, the density of $\mathrm{BrdU}^{+}$cells was significantly lower in mice than in rats at the 4 week time point. Since very few $(\approx 5 \%) \mathrm{BrdU}^{+}$cells expressed the proliferation marker PCNA at the 1 week time point in mice or rats, and this value was not different across species $(t$ test, $p=0.4)$ (supplemental Fig. 2, available at www.jneurosci.org as supplemental material), loss of 
$\mathrm{BrdU}^{+}$cells between 1 and 4 weeks after injection reflects cell death, and not BrdU dilution, in both species, consistent with previous findings (Dayer et al., 2003; Mandyam et al., 2007). Together, these findings indicate that initial production of granule cell precursors occurs at a similar rate in mice and rats, relative to the total population of granule cells, but more than twice as many of the new neurons survive in rats.

\section{Relatively few granule cells survive to maturity in mice}

Because of the sizable species difference observed in the proportion of new cells lost during the first month, we compared the total numbers of mature and immature cells at each time point by multiplying total $\mathrm{BrdU}^{+}$cell numbers at each point by the percentage of $\mathrm{BrdU}^{+}$cells expressing the late neuronal marker $\mathrm{NeuN}$ and the early neuronal maker DCX (Fig. $2 D-G)$. In the rat, the number of $\mathrm{DCX}^{+}$ (immature) cells drops at a steady rate from 1 week to 3 weeks after BrdU injection (Fig. $2 D)$. Over this same time period, there is a nearly equivalent accumulation of $\mathrm{DCX}^{-}$ cells, indicating that the loss of $\mathrm{DCX}^{+}$cells in rats is largely due to their maturation into $\mathrm{DCX}^{-}$cells. In mice (Fig. $2 E$ ), loss of $\mathrm{DCX}^{+}$ cells occurs $\sim 1$ week later than in rats, between 2 and 4 weeks after cell birth, but occurs at a similar rate during the 2 week period. The change in $\mathrm{DCX}^{-}$cells over this time period, however, looks very different from that in rats. Despite a steady loss of $\mathrm{DCX}^{+}$cells, the number of mature, $\mathrm{DCX}^{-}$ cells does not increase at all until 4 weeks, when it shows a very modest increase. Very few mature, $\mathrm{DCX}^{-}$cells are produced in the mouse.

$\mathrm{NeuN}^{-}$(immature) cells are lost between 1 and 4 weeks in rats (Fig. 2F), with the largest drop between 1 and 2 weeks and no $\mathrm{NeuN}^{-}$cells remaining by 4 weeks. $\mathrm{NeuN}^{+}$neurons are gained on a similar time course and scale, indicating that many $\mathrm{NeuN}^{-}$ cells become $\mathrm{NeuN}^{+}$cells. In mice (Fig. $2 G$ ), the largest drop in $\mathrm{NeuN}^{-}$cells occurs between 2 and 3 weeks, one week later than in rats. $\mathrm{NeuN}^{+}$(mature) neurons increase steadily between 1 and 3 weeks, but the increase in $\mathrm{NeuN}^{+}$cells is much smaller than the decrease in $\mathrm{NeuN}^{-}$cells, indicating that there is much more cell death than neuronal maturation.

\section{Additional rat and mouse strains show the same species differences}

The rate of adult neurogenesis varies up to twofold across 11 commonly used mouse strains (Kempermann et al., 1997a; Kempermann and Gage, 2002; Balu et al., 2009; Kim et al., 2009a), suggesting that the species differences observed here may not hold for all strains. However, C57BL/6 mice, used for the experiments above, show the highest cell proliferation rate and thirdhighest rate of overall neurogenesis of these strains, suggesting that mice in nearly all background strains would show an even greater difference from rats. To further investigate whether spe-
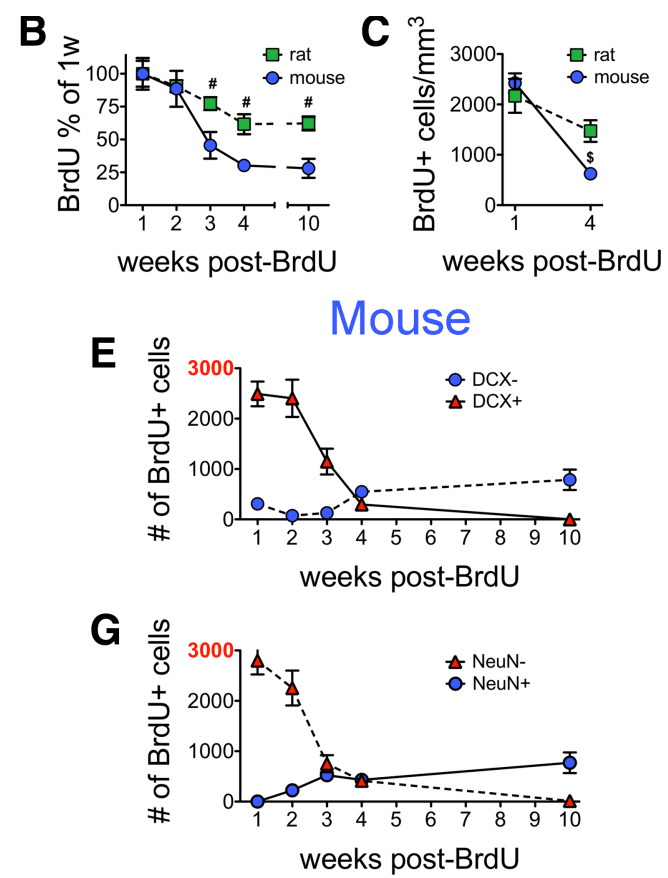

Figure 2. Magnitude of neurogenesis in mice and rats. $A-C$, Loss of BrdU ${ }^{+}$cells over time. $A$, Rats had significantly more BrdU ${ }^{+}$ mice at all time points $\left(F_{(1,32)}=232, p<0.0001\right.$ for main effect of species and $F_{(4,32)}=9.9, p<0.0001$ for main effect (3,25) $=16, p<0.0001$ for main effect of cell age). $C$, Normalizing to the volume of the granule cell layer revealed that the ars loss of immature neurons, due to martion and cell death combined, occurs at approximately the same time course in both species. In rats, the loss of immature cells is largely balanced by growth of the mature neuronal population, while in mice slow 侻 and increased cell death result in negligible growth of the mature neuronal population. ${ }^{\#} p<0.05$, ${ }^{*} p<0.001$ post hoc versus mouse at the same time point, following two-way (species $\times$ cell age) ANOVA, ${ }^{5} p<0.001$ for post hoc comparison between 1 week and 4 weeks in mice.

cies differences seen between C57BL/6 mice and Sprague Dawley rats are found in other mouse and rat strains, we examined CD1 mice and Long-Evans rats. CD1 mice show the greatest survival rate and overall rate of neurogenesis of any tested mouse strain (Kempermann et al., 1997a; Kempermann and Gage, 2002; Balu et al., 2009; Kim et al., 2009a), and Long-Evans rats are widely used in behavioral experiments. Consistent with the findings from C57BL/6 mice and Sprague Dawley rats, DCX was expressed significantly longer, and the onset of NeuN expression was delayed, in new neurons from CD1 mice compared with Long-Evans rats (Fig. $3 A, B$ ). BrdU counts were greater in LongEvans rats than CD1 mice at all time points. By 4 weeks, $63 \%$ of cells labeled at the 1-week time point remained in Long-Evans rats, whereas only $40 \%$ remained in CD1 mice (Fig. 3D). Comparing across all 4 strains, the proportion of cells surviving was higher in both rat strains compared with both mouse strains (Fig. $3 E$ ). Expressed relative to granule cell layer volume, the density of $\mathrm{BrdU}+$ cells was lower at both the 1 week and 4 week time points in CD1 mice compared with Long-Evans rats; therefore, unlike $\mathrm{C} 57 \mathrm{BL} / 6$ mice, both initial neuron production and survival is reduced in CD1 mice relative to rats. Long-Evans rats also showed much greater growth of the mature neuronal population than CD1 mice (Fig. 3G-J). Furthermore, the number of immature $\mathrm{BrdU}^{+}$ 
A

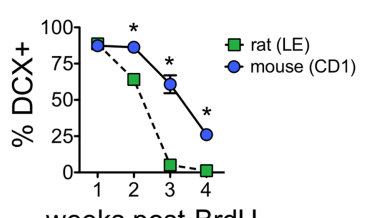

C

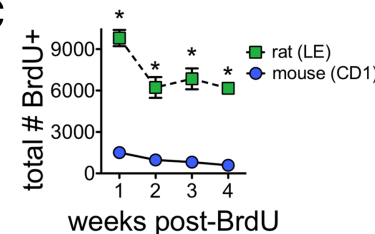

E

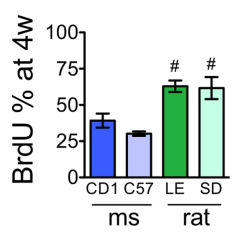

G

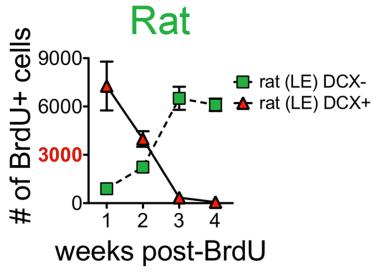

I

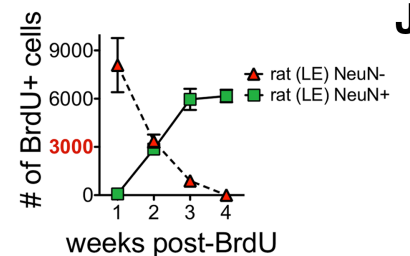

B

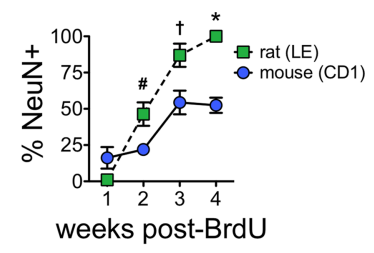

D

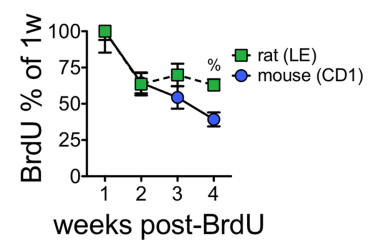

$F$

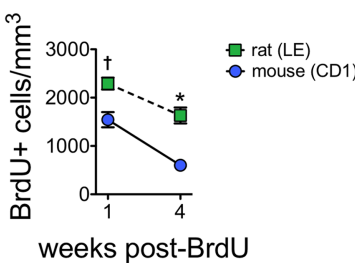

H

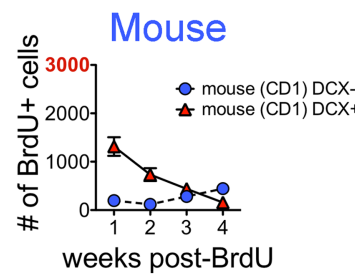

J

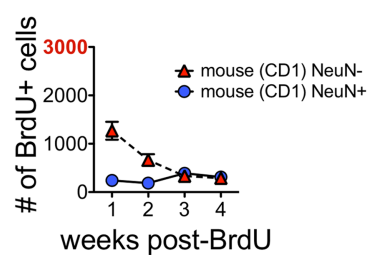

Figure 3. Additional strains of mice and rats confirm species differences in maturation rate and magnitude of neurogenesis. $\boldsymbol{A}$, Immunostaining for $D C X$ in young granule cells was prolonged in young neurons in $C D 1$ mice compared with young neurons in Long-Evans rats $\left(F_{(1,46)}\right.$ $=103, p<0.0001$ for main effect of species, $F_{(3,46)}=197, p<0.0001$ for main effect of cell age, and $F_{(3,46)}=21, p<0.0001$ for their interaction). $\boldsymbol{B}$, Onset of strong expression of the late neuronal marker NeuN was delayed in CD1 mice compared with Long-Evans rats $\left(F_{(1,46)}=24\right.$, $p<0.0001$ for main effect of species, $F_{(3,46)}=48, p<0.0001$ for main effect of cell age, and $F_{(3,46)}=8.3, p<0.001$ for their interaction). $C$, The total number of $\mathrm{BrdU}^{+}$neurons was greater in rats compared with mice $\left(F_{(1,45)}=463, p<0.0001\right.$ for main effect of species, $F_{(3,45)}$ $=12, p<0.0001$ for main effect of cell age, and $F_{(3,45)}=5.4, p<0.01$ for their interaction). $D$, The proportion of new cells surviving to 4 weeks of age was $58 \%$ greater in Long-Evans rats than in CD1 mice (Fisher's post hoc, $p=0.06$ ). $E$, The proportion of 1-week-old cells surviving to 4 weeks of age was significantly greater in both rat strains than in both mouse strains $\left(F_{(3,18)}=\right.$ 9.5, $p<0.001$ for 1 -way ANOVA, ${ }^{\#} p<0.05$ for post hoc tests). $\boldsymbol{F}$, The density of BrdU ${ }^{+}$cells was lower in mice than in rats at both time points $\left(F_{(1,23)}=43, p<0.0001\right.$ for main effect of species, and $F_{(1,23)}=35, p<0.0001$ for main effect of cell age) $\boldsymbol{G}, \boldsymbol{H}$, The total number of young, $\mathrm{DCX}{ }^{+}$neurons declined to zero at approximately the same rate in both rats $(\boldsymbol{G})$ and mice $(\boldsymbol{H})$. Loss of immature neurons was balanced by growth of the mature, $\mathrm{DCX}^{-}$population in Long-Evans rats but less so in CD1 mice. $I, J$, The total number of immature, NeuN ${ }^{-}$cells declined over 4 weeks in rats $(\boldsymbol{I})$ and mice $(\boldsymbol{J})$. Growth of the mature, $\mathrm{NeuN}^{+}$population was substantial in rats but minimal in mice. $0.05<{ }^{\%} p<0.1,{ }^{\#} p<0.05,{ }^{\dagger} p<0.01,{ }^{*} p<0.001$ post hoc versus mouse at the same time point, following two-way (species $\times$ cell age) ANOVA $(A-D, F)$.

cells present 1 week after BrdU injection was lower in CD1 mice than in Long-Evans rats even after accounting for the threefold difference in total granule cell number between the 2 species. Together, these findings suggest that delayed maturation and decreased survival of

A
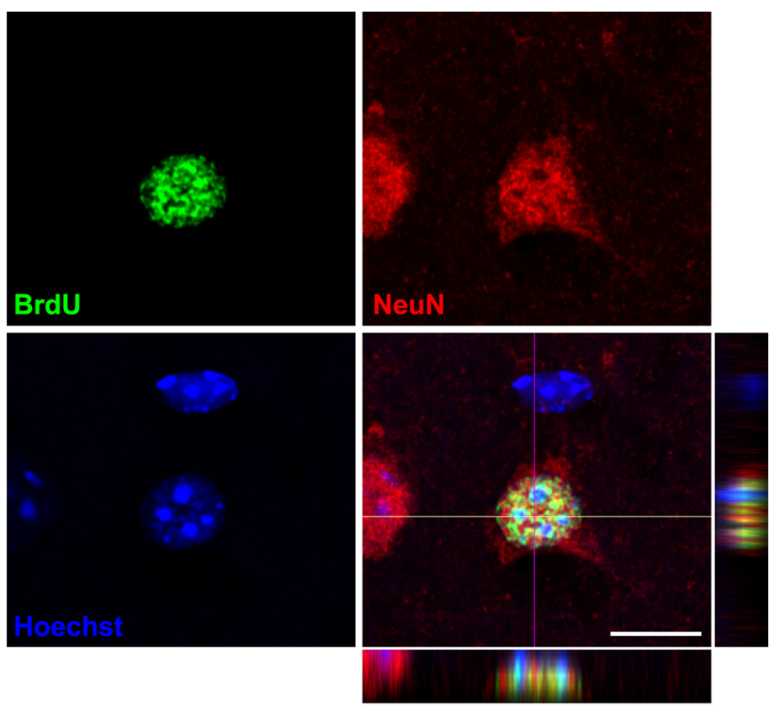

B
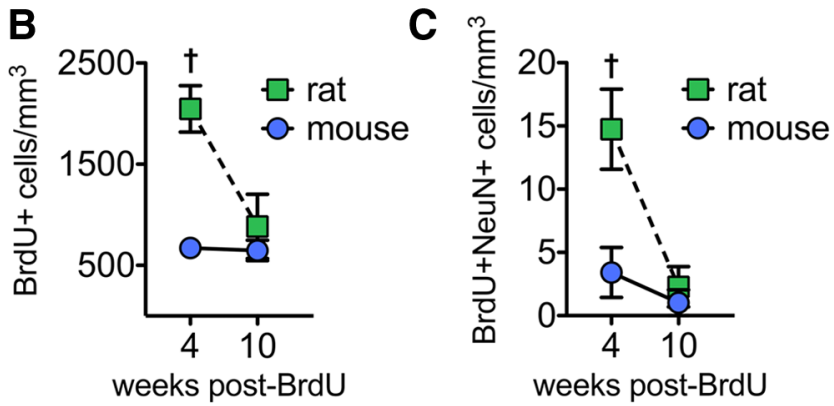

Figure 4. Mouse-rat differences in neocortical adult neurogenesis. $\boldsymbol{A}$, Confocal photograph of a 28 -d-old neuron in the mouse neocortex. $\boldsymbol{B}$, The density of $\mathrm{BrdU}^{+}$cells, regardless of phenotype, was significantly greater in rats at 4 weeks $\left(F_{(1,12)}=15, p<0.01\right.$ for main effect of species, $F_{(1,12)}=8.1, p<0.05$ for main effect of cell age, and $F_{(1,12)}=7.5$, $p<0.05$ for species $\times$ cell age interaction). $C$, The density of adult-born neocortical neurons, double-labeled with BrdU and NeuN, was five times higher in rats than in mice at 4 weeks $\left(F_{(1,12)}=9.1, p<0.05\right.$ for main effect of species, $F_{(1,12)}=13, p<0.01$ for main effect of cell age, and $F_{(1,12)}=5.8, p<0.05$ for their interaction). Rats showed significant cell death between 4 and 10 weeks ( $p<0.01$ post hoc). Scale bar, $10 \mu \mathrm{m} .{ }^{\dagger} p<0.01$ post hoc versus mouse at the same time point, following two-way (species $\times$ cell age) ANOVA.

new neurons is a feature of laboratory mice in general, relative to rats, and not a feature of a particular mouse strain.

\section{The species difference extends to the neocortex}

To determine whether a higher rate of neurogenesis in rats than mice occurs in other brain regions, $\mathrm{BrdU}^{+} / \mathrm{NeuN}^{+}$cells were quantified in the neocortex and striatum 4 and 10 weeks after BrdU injection. The $\mathrm{BrdU}^{+} / \mathrm{NeuN}^{+}$neuron density in the neocortex was significantly higher in rats than mice (Fig. $4 C$ ). This difference was specific to the 4 week time point, when the density of $\mathrm{BrdU}^{+} / \mathrm{NeuN}^{+}$neurons was five times higher in rats than mice. While this and earlier studies (Dayer et al., 2003; Kempermann et al., 2003) have shown that cell death is complete in the hippocampus of both species within 4 weeks, the rat neocortex showed a $57 \%$ loss of BrdU ${ }^{+}$cells and $85 \%$ loss of $\mathrm{BrdU}^{+} / \mathrm{NeuN}^{+}$ neurons and between 4 and 10 weeks of age (Fig. $4 B$ ). In contrast, the mouse neocortex showed no loss of $\mathrm{BrdU}^{+} / \mathrm{NeuN}^{+}$or $\mathrm{BrdU}^{+}$cells over this interval. In the striatum, another region in which low levels of adult neurogenesis have been reported (Dayer et al., 2005), no differences in $\mathrm{BrdU}^{+} / \mathrm{NeuN}^{+}$cell density were found across species or across the interval from 4 weeks to 10 weeks postinjection (sup- 


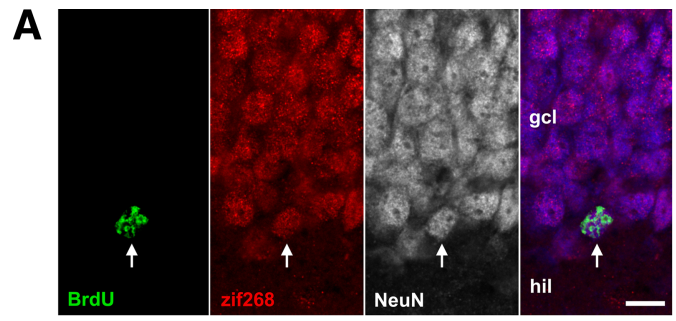

B
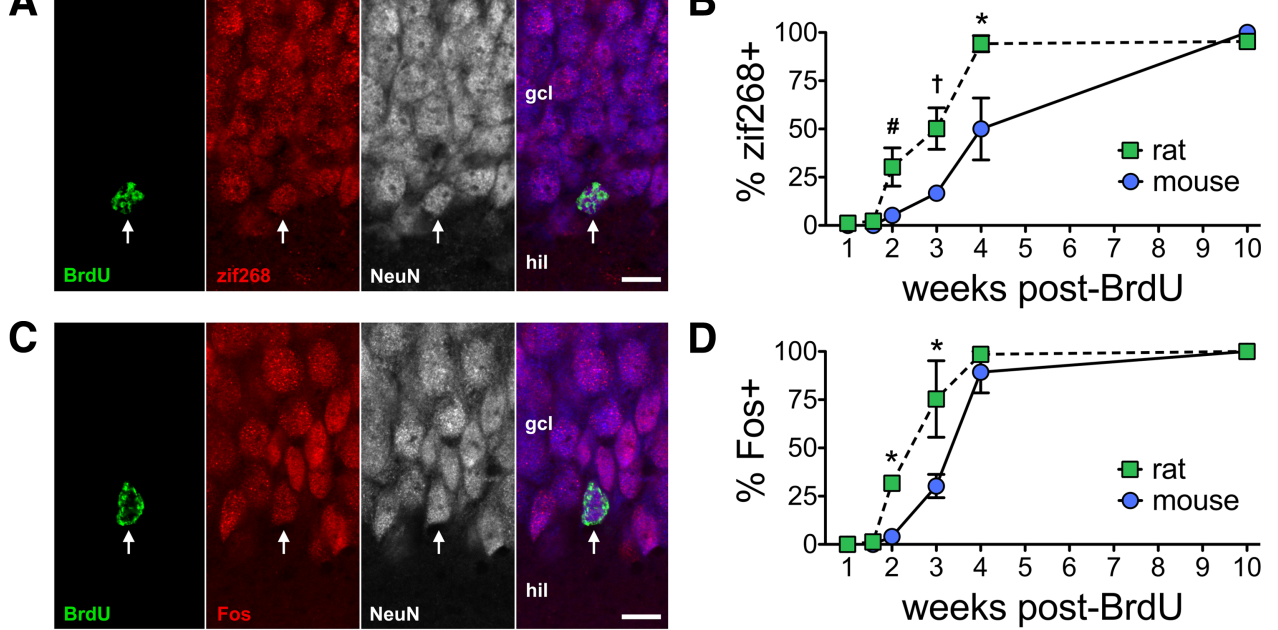

E

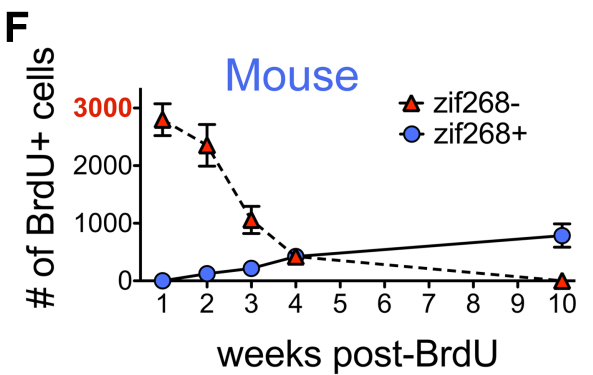

Figure 5. Age-dependent expression of immediate early genes after supraphysiological stimulation (kainate seizures). $\boldsymbol{A}$, Immunostaining for zif268 is seen throughout the granule cell layer after kainate injection, including in a 10-week-old BrdU ${ }^{+}$mouse neuron (arrow), indicating functional integration. $B$, Seizure-induced immunostaining for zif268 is seen earlier in BrdU ${ }^{+}$cells in rats than in mice $\left(F_{(1,35)}=17, p<0.001\right.$ for main effect of species, $F_{(5,35)}=51, p<0.0001$ for main effect of cell age, and $F_{(5,35)}=3.7, p<0.01$ for their interaction). $C$, Immunostaining for Fos after kainate injection in a 3-week-old neuron from a rat (arrow). D, Seizure-induced immunostaining for Fos occurs at a younger age in rat cells than in mouse cells $\left(F_{(1,31)}=33, p<0.0001\right.$ for main effect of species, $F_{(5,35)}=225, p<0.0001$ for main effect of cell age, and $F_{(5,31)}=9.7, p<0.0001$ for their interaction). $\boldsymbol{E}$, In rats, growth of the total population of new cells capable of expressing zif268 after seizures largely balances out the decline in the zif268 ${ }^{-}$population. $\boldsymbol{F}$, The zif $268+$ population shows relatively little growth in mice. A threefold difference in $y$-axis scales in $\boldsymbol{E}$ and $\boldsymbol{F}$ normalizes for the threefold greater total granule cell number in rats. Scale bars, $10 \mu \mathrm{m} ; \mathrm{gcl}$, granule cell layer; hil, hilus; ${ }^{\#} p<0.05,{ }^{\dagger} p<0.01,{ }^{*} p<0.001$ post hoc versus mouse at the same time point, following two-way (species $\times$ cell age) ANOVA.

plemental Fig. 3, available at www.jneurosci.org as supplemental material).

Functional maturation assessed by immediate-early gene expression is more rapid in rats than mice

Expression of NeuN and lack of expression of DCX expression are commonly used as indications of neuronal maturation, but inducible expression of immediate-early genes likely provides a better measure of functional maturation. Therefore, to assess the proportion of granule cells at each age that were integrated into the circuitry and could be activated by very strong stimulation, expression of zif268 in response to kainate seizures was measured in 1-week-old to 10 -week-old $\mathrm{BrdU}^{+}$cells in the dentate gyrus. The proportion of $\mathrm{BrdU}^{+}$cells expressing zif268 increased significantly over this time period in both mice and rats, but the two species differed significantly in their time courses of zif268 expression (Fig. $5 B)$. Rats had significantly higher expression of zif268 than mice in 2-week-old, 3-week-old, and 4-week-old cells. By 10 weeks after BrdU injection, $>95 \%$ of BrdU-labeled cells in both rats and mice had strong zif268 expression after kainate seizures.

Expression of Fos following kainate-induced seizures showed a pattern similar to zif268 expression, with higher expression in young granule cells in rats than mice at both 2 and 3 weeks after BrdU injection time points (Fig. 5D).

The number of young cells that are zif $268^{-}$after seizures, i.e., those that were not activated and likely not synaptically inte- grated, dropped steadily between 1 week and 4 weeks in rats (Fig. $5 E)$, at which time there were almost none of these immature cells remaining. Zif $268^{+}$cells in rats increase steadily over the same time course, reaching a peak at 4 weeks of $5155 \mathrm{BrdU}^{+} / \mathrm{zif}^{+} 68^{+}$ cells, or $58 \%$ of the total starting number of $8897 \mathrm{BrdU}^{+}$cells, suggesting that $\sim 40 \%$ of the cells die and $60 \%$ mature into neurons that are activated by kainate-induced seizures. In mice, the loss of zif $268^{-}$cells occurred relatively steadily over the entire time period examined, similar to what was seen in rats (Fig. $5 F$ ). However, as with the other markers (Fig. 2), the loss of zif268 cells was offset by an almost negligible increase in zif $268^{+}$cells in mice; by 4 weeks there were only 423 cells, or $15 \%$ of the original $2799 \mathrm{BrdU}^{+}$cells. By 10 weeks, when all cells in mice had matured, there were $786 \mathrm{BrdU}^{+} /$zif $268^{+}$cells in mice $(28 \%$ of original 1 week BrdU population) and $5575 \mathrm{BrdU}^{+} /$zif $268^{+}$cells in rats (63\%). Thus, the proportion of 1-week-old neurons that matured to a functional state was $4 \times$ larger in rats than mice at 4 weeks and $>2 \times$ as large at 10 weeks. The total number of these cells was $12 \times$ larger and $7 \times$ larger, respectively, at these time points.

\section{Spatial learning activates more new granule cells in rats than mice}

The results above indicate that new neurons in the adult rat dentate gyrus mature faster and are more numerous in rats than in mice. However, they do not reveal whether significant differences also exist in the way adult-born granule neurons are activated 
A

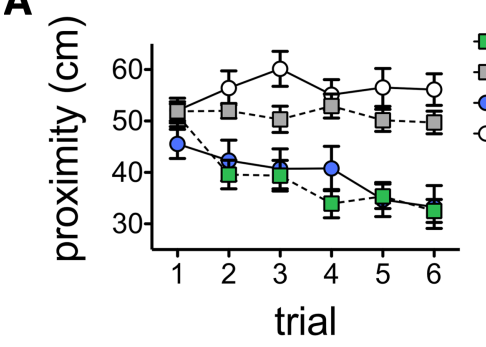

C

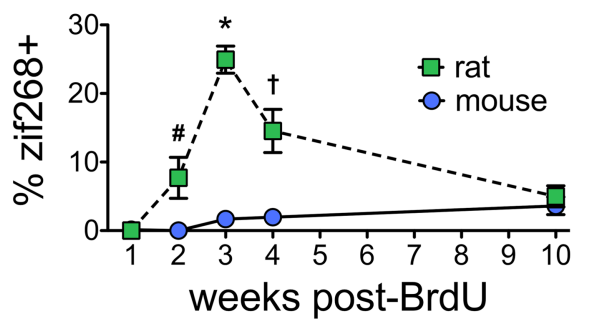

B

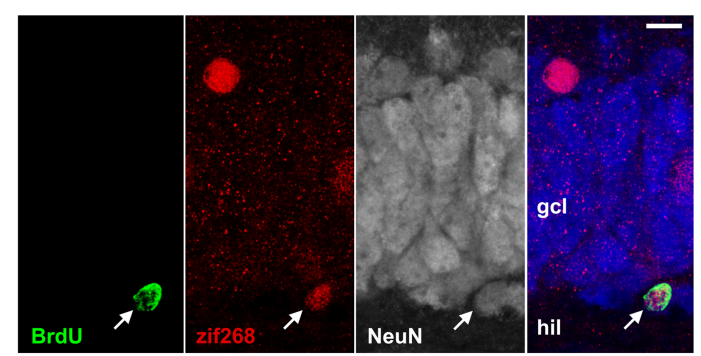

D

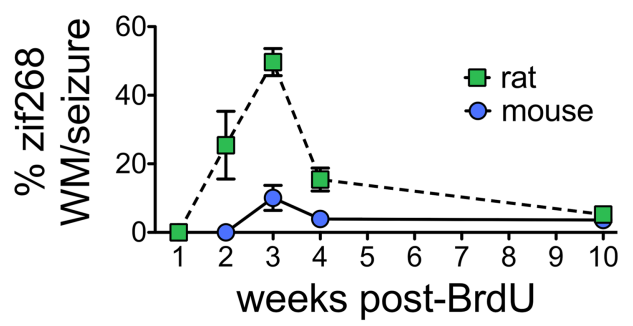

Figure 6. Age-dependent expression of zif268 after physiological stimulation (water maze training). $A$, The proximity to the correct platform location (within-trial mean distance to platform) decreased over trials (2-way repeated-measures ANOVA, $F_{(5,180)}=6.8, p<0.0001$ for main effect of trial) and was not different between rats and mice $\left(F_{(1,180)}=0.17, p=0.69\right.$ for main effect of species) during the final spatial training session. For both species there was a main effect of platform location, with the proximity to the target location being less than the equivalent location in the opposite quadrant of the pool (platform location $\times$ trial repeated-measures ANOVAs, $p<0.0001$ for main effects of location), indicating that both mice and rats showed a spatial bias for the correct location during training. $\boldsymbol{B}$, Confocal photograph of a 28 -d-old BrdU ${ }^{+}$neuron (arrow) in a rat labeled with zif268 after water maze training. $\boldsymbol{C}$, The proportion of BrdU ${ }^{+}$cells expressing zif268 was greater in rats than mice at 2,3 , and 4 weeks $\left(F_{(1,29)}=46, p<0.0001\right.$ for main effect of species, $F_{(4,29)}=10.4, p<0.0001$ for main effect of cell age and $F_{(4,29)}=9.4, p<0.0001$ for their interaction). Expression peaked in 3-week-old cells in rats, whereas in mice expression increased gradually to maximal levels in 10 -week-old cells. $D$, Water maze-induced activation normalized to the seizure-induced levels of activation. The greatest behavioral activation of the functional (seizure-inducible) population of new neurons occurs at 3 weeks of age in both mice (10\%) and rats (50\%). Scale bar, $10 \mu \mathrm{m}$; gcl, granule cell layer; hil, hilus. ${ }^{\#} p<0.05,{ }^{\dagger} p<0.01,{ }^{*} p<0.001$ post hoc versus mouse at the same time point, following two-way (species $\times$ cell age) ANOVA.

during normal physiological situations. Mice might, for example, have less neurogenesis than rats but compensate by recruiting a larger proportion of young neurons during learning. To address this possibility we examined activation of young neurons by a hippocampus-dependent learning stimulus, the spatial water maze task. Rats and mice were given nonspatial and simple spatial pretraining (supplemental Fig. 4, available at www.jneurosci.org as supplemental material), which enabled animals of both species to learn to spatially navigate to a hidden platform in a novel environment in a single block of training (Fig. $6 \mathrm{~A}$ ). Active young neurons were identified by triple immunofluorescent labeling for BrdU, NeuN, and zif268 (Fig. $6 \mathrm{~B}$ ). The proportion of new neurons expressing zif268 changed over time, and this time course differed significantly between mice and rats (Fig. 6C): more young neurons expressed zif268 in rats than mice at the 2 week, 3 week, and 4 week time points, consistent with faster maturation in rats. At 1 week, when new neurons could not be activated even by seizure activity in either species, and at 10 weeks, when new neurons in both species have fully matured, young neuronal activity is similar in mice and rats. The dynamics of zif268 expression suggest that immature neurons in rats show a peak in responsiveness at 3 weeks of age, when $25 \%$ of cells were active. In contrast, zif268 expression in mice increased gradually across the time points examined to a maximal value of $4 \%$ at 10 weeks.

The seizure activation data (Fig. 5) indicate that not all young neurons are capable of activity-dependent IEG expression at the earlier time points (1-4 weeks). Therefore, the percentage of cells expressing zif268 following the water maze underestimates activation of the functional population, since many nonfunctional neurons are included in this calculation. To estimate the proportion of functional neurons that express zif268 after water maze training, the zif268 values from the water maze experiment (Fig. $6 C$ ) were divided by the mean seizure-induced zif268 values (Fig. $5 B)$. Within the functional population of young neurons, rats again had more activated cells than mice (Fig. 6D). The magnitude of activity in 3-week-old neurons in rats was especially pronounced: $50 \%$ of the functional population expressed zif268 at this age. In mice, a much smaller proportion of the functional population is activated by water maze training. However, unlike activity for the total population (Fig. 6C), activity within the functional population in mice showed a peak at 3 weeks $(10 \%)$ and declined by 10 weeks (4\%) (Fig. 6D). Thus, at 3 weeks, not all young neurons have functionally integrated but those that have are more likely to be active during learning than their mature counterparts. The preferential activation of young neurons seen here extends previous work showing that, while not all immature neurons have afferent synapses, those that do receive excitatory synaptic input are more likely than mature neurons to exhibit LTP in acute slices (Ge et al., 2007). This analysis was limited to the rostral dentate gyrus, the region more strongly associated with spatial learning, to compare similar populations in the two species. Even greater activation of young granule cells might be expected in the ventral dentate gyrus in rats, based on our recent findings regarding c-fos activation (Snyder et al., 2009a), although it is not clear whether mice would show the same gradient.

\section{Inhibition of neurogenesis impairs contextual fear conditioning in rats but not mice}

The faster maturation and larger number of new neurons added to the rat dentate gyrus suggests that new neurons may make a greater contribution to behavior in rats than in mice. To test this hypothesis, we irradiated the brains of mice and rats to inhibit neurogenesis and examined contextual fear conditioning 4 and 8 weeks later. The reduction in neurogenesis was confirmed in all irradiated animals-virtually no young, doublecortin-positive neurons were found in irradiated rats and mice at either time point, whereas many young neurons were found in control animals (Fig. 7). Eight weeks after irradiation, when a large popula- 

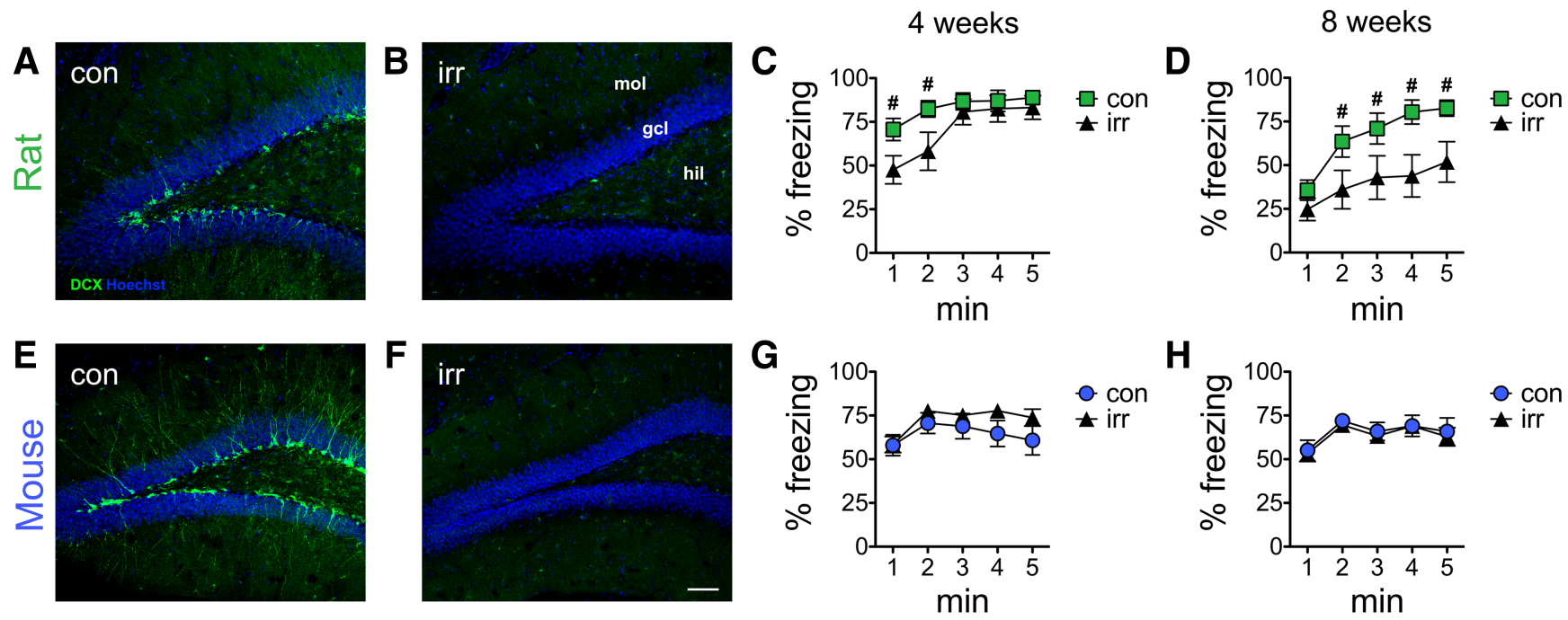

Figure 7. Inhibition of neurogenesis impairs contextual fear memory in rats. $\boldsymbol{A}, \boldsymbol{B}, \boldsymbol{E}, \boldsymbol{F}$, Young, $D C X^{+}$, neurons were numerous in the dentate gyrus of control rats $(\boldsymbol{A})$ and mice $(\boldsymbol{E})$ but were absent from irradiated rats $(\boldsymbol{B})$ and mice $(\boldsymbol{F})$. C, Rats irradiated 4 weeks earlier showed decreased $24 \mathrm{~h}$ fear memory upon reexposure to the conditioned context compared with controls, as reflected by reduced freezing behavior $\left(F_{(4,104)}=2.3, p<0.05\right.$ for treatment $\times$ time interaction in 2-way repeated-measures ANOVA). $D$, Rats irradiated 8 weeks earlier showed greater memory impairment $\left(F_{(1,72)}=5.6, p<0.05\right.$ for main effect of treatment). $\mathbf{G}, \boldsymbol{H}$, However, irradiation did not affect freezing behavior in mice upon reexposure to the conditioned context at either the 4 week ( $\left.\boldsymbol{G}\right)$ or 8 week (H) time points. Scale bar, $200 \mu \mathrm{m}$; hil, hilus; gcl, granule cell layer; mol, molecular layer; ${ }^{\#} p<0.05$ in post hoc tests.

tion of young neurons is absent, irradiated rats had a pronounced memory deficit, as indicated by reduced freezing in the conditioning context compared with control, sham-irradiated, rats (Fig. 7D). Four weeks after irradiation, when fewer young neurons are absent, we found a modest impairment in contextual fear conditioning; irradiated rats froze less during the first $2 \mathrm{~min}$ of the test than controls, indicating a weaker memory for the context (Fig. 7C). No contextual fear impairment was found in a separate group of rats tested 3 weeks after irradiation (supplemental Fig. 5, available at www.jneurosci.org as supplemental material). Freezing to the conditioned tone was not impaired in irradiated rats at any time point, indicating that the deficit is not due to global/nonspecific effects of irradiation on freezing and memory (supplemental Fig. 6, available at www.jneurosci.org as supplemental material). Thus, the contextual memory deficit in rats increases with time since irradiation, consistent with the time course of maturation of new neurons. Irradiated mice showed no effect of irradiation on contextual fear memory either 4 or 8 weeks after irradiation (Fig. 7G,H). It is possible that this lack of effect of irradiation in mice reflects a $\geq 4$ week delay in maturation of granule cells in mice. However, this explanation seems unlikely because our neuronal marker and IEG data indicate a delay in maturation of $\sim 2$ weeks in mice compared with rats. A more likely explanation for these results, then, appears to be that the behavioral impairment observed in irradiated rats, but not mice, reflects the much larger number of new neurons produced and greater recruitment of young neurons during learning, in rats compared with mice.

\section{Discussion}

This study demonstrates four major differences in adult neurogenesis between rats and mice. First, there is a 1-2 week delay in the maturation of young granule cells in mice. A delay was observed both in the downregulation of early markers as well as in the onset of the late neuronal marker NeuN. Seizure-induced expression of activity-dependent immediate-early genes was also delayed by 1-2 weeks in mice, suggesting a delay in the formation of functional synapses. Second, the numbers of mature, activat- able, new granule neurons are dramatically lower in mice than rats. This is true even after normalizing for the $3 \times$ larger granule cell population in rats than in mice (West and Andersen, 1980). Granule cell precursor proliferation is equivalent in rats and C57BL/6 mice, relative to population size (though lower in CD1 mice), but many more new neurons survive in rats. These differences were also found using two mouse strains with the highest rates of neurogenesis, suggesting that they are general features of these two species and not highly strain-dependent. Large differences in $\mathrm{BrdU}^{+} / \mathrm{NeuN}^{+}$cell density in the neocortex suggest that greater adult neurogenesis in rats is not limited to the dentate gyrus. Third, many more young neurons are activated in rats than in mice during hippocampus-dependent behaviors. The proportion of young neurons expressing the activation marker zif268 following water maze training was as much as five times higher in rats than in mice, even after accounting for the species differences in the rate of functional maturation. The total number of 3-weekold neurons activated by the water maze was $>80 \times$ greater in rats than in mice $-30 \times$ greater if adjustments are made for the smaller hippocampus in the mouse. This difference reflected $3 \times$ higher initial neuronal production or 1 week $\mathrm{BrdU}^{+}$cell number in rats (no difference if relative hippocampal size is factored in), $2 \times$ greater survival between 1 week and 3 weeks, $3 \times$ more functionally mature 3 -week-old cells (showing seizure-induced zif268), and $5 \times$ more activation of the functional population during learning. Fourth, inhibiting adult neurogenesis produced memory impairments in rats but not mice, consistent with a greater functional impact of adult neurogenesis in rats than in mice.

One of the major goals of research on adult neurogenesis is to uncover the role of new neurons in hippocampal functions such as learning and memory or anxiety-like behaviors. Many of the behavioral effects of reduced adult neurogenesis have been found in rats. Behavioral deficits in hippocampus-dependent tasks have been observed as soon as 17-20 d (Shors et al., 2001, 2002; Madsen et al., 2003; Bruel-Jungerman et al., 2005) or 4 weeks (Winocur et al., 2006; Wojtowicz et al., 2008) after inhibition of neurogenesis 
with irradiation or methylazoxymethanol acetate. In light of the immaturity of granule neurons at this age, observed in electrophysiological and morphological studies (Jessberger and Kempermann, 2003; Espósito et al., 2005; Ge et al., 2006, 2007; Zhao et al., 2006; Toni et al., 2007), it has been difficult to imagine how the young neurons could play a role in hippocampal function. However, these electrophysiological and morphological studies have all been performed in mice, which show delayed granule cell maturation relative to rats, as seen here.

Our data are the first to provide a detailed time course of the functional maturation of new neurons in rats. Importantly, our marker and IEG time courses in mice correlate well with the published morphological and electrophysiological rates of maturation, indicating these markers and IEGs provide good substitutes for electrophysiological measurement of synapse formation. The different rates of maturation that we present reconcile the apparent inconsistency between the aforementioned maturation and behavioral impairment studies by suggesting that neurons born in adult rats mature more rapidly than those in mice, so these neurons could contribute to behavior at a younger age in rats than in mice. Notably, the published literature in mice likely reflects a state of enhanced maturation, since most electrophysiological and morphological studies of mice have studied animals housed with running wheels, which accelerates maturation of young neurons (Snyder et al., 2009b). The small number of electrophysiological studies of young neurons in rats are consistent with our findings, as they show significant excitatory synaptic input, longterm potentiation, and IEG expression in cells $\leq 3$ weeks old (Snyder et al., 2001; Schmidt-Hieber et al., 2004; BruelJungerman et al., 2006; Karten et al., 2006; Ambrogini et al., 2009). Conversely, studies that have observed behavioral impairments with loss of young neurons in mice inhibited neurogenesis for 6-12 weeks, i.e., much longer than in rat studies (Saxe et al., 2006, 2007; Imayoshi et al., 2008).

Our findings suggest that young neurons are more activated by experience and make a greater contribution to behavior in rats than in mice. Blocking neurogenesis produced contextual fear memory impairments in rats that increased with time postirradiation at a rate that matched the maturation time course. In contrast, inhibiting neurogenesis in mice did not produce any memory impairments, even 8 weeks postirradiation, when the missing neurons would have been relatively mature and functionally integrated. Our results seemingly contradict other findings showing contributions of adult neurogenesis to fear conditioning in mice (Saxe et al., 2006; Imayoshi et al., 2008). However, the majority of studies (Clark et al., 2008; Dupret et al., 2008; Pollak et al., 2008; Zhang et al., 2008; Jaholkowski et al., 2009) have found no effects of inhibiting adult neurogenesis on contextual fear conditioning in mice, consistent with our finding. There is no clear methodological difference that can account for these disparate findings. However, when taken together with the current findings we conclude that while adult neurogenesis may contribute to mouse behavior, its role is more difficult to observe than in rats. One major difference between the rat dentate gyrus and mouse dentate gyrus is that the peak of granule cell development is postnatal in the rat but prenatal in the mouse (Angevine, 1965; Schlessinger et al., 1975), despite the nearly identical gestation time in these two species. The later development of the dentate gyrus in the rat may result in a structure that is more adaptable to changing external environments and more plastic in adulthood. Behaviorally, this could result in rats having a greater bias than mice toward behavioral strategies that require sig- nificant plasticity (Whishaw et al., 2001) and/or that strongly rely on the hippocampus (Gerlai and Clayton, 1999).

The differences in adult neurogenesis between mice and rats could reflect a number of genetic and/or environmental factors. Environmental factors such as housing enrichment, learning, and stress can all affect the survival rate of young granule cells (Kempermann et al., 1997b; Leuner et al., 2004; Snyder et al., 2009b). While the animals used in our experiments were standard control animals, it is possible that unidentified features of the standard laboratory housing environment, e.g., group housing or ad libitum unvaried diet, may be differentially enriching or stressful for rats and mice, resulting in greater survival and accelerated maturation of young granule cells in rats. In vitro comparisons between mouse- and rat-derived progenitor cells (Ray and Gage, 2006), as well as the differences in dentate gyrus development described above, suggest that genetic effects on adult neurogenesis could be responsible for the observed species differences. In vivo comparisons across mouse strains (Kempermann et al., 1997a; Kempermann and Gage, 2002) also suggest genetic influences on adult neurogenesis, although cross-fostering studies suggest that many hippocampus-related strain differences may reflect early life experience rather than genes (Zaharia et al., 1996; Caldji et al., 2004). Given the known strain differences in rates of adult neurogenesis, one concern is that the mouse-rat differences seen in the current study might be specific to the strains used. However, C57BL/6 and outbred CD1 mice both showed similarly delayed maturation and decreased survival relative to the two rat strains used in the current study. Since these two mouse strains have the highest rates of cell proliferation (C57BL/6), granule cell survival (CD1), and overall neurogenesis (CD1) of 11 commonly used mouse strains previously tested (Kempermann et al., 1997a; Kempermann and Gage, 2002; Balu et al., 2009; Kim et al., 2009a), the current findings likely reflect a general feature of mice, at least in the laboratory setting. Which of these two species shows rates of neurogenesis more like humans is not known. However, the prolonged development and more complex and flexible behavioral repertoire of the rat compared with mouse (Whishaw et al., 2001) suggest that the rat hippocampus may be the better model for that of the human. The densities of new neurons observed at long survival times in humans (Eriksson et al., 1998), despite relatively advanced age and low doses of BrdU ( $\sim 10-60$ times lower than doses used in rodents), suggest that the number of new neurons produced in humans may be even higher than that in rats. In any case, these findings clearly indicate that adult neurogenesis differs dramatically between mice and rats and emphasize the need to carefully consider species differences when studying adult neurogenesis.

\section{References}

Ambrogini P, Cuppini R, Lattanzi D, Ciuffoli S, Frontini A, Fanelli M (2009) Synaptogenesis in adult-generated hippocampal granule cells is affected by behavioral experiences. Hippocampus. Advance online publication. Retrieved July 23, 2009. doi:10.1002/hipo.20679.

Angevine JB Jr (1965) Time of neuron origin in the hippocampal region. An autoradiographic study in the mouse. Exp Neurol Suppl [Suppl 2]:1-70.

Balu DT, Hodes GE, Anderson BT, Lucki I (2009) Enhanced sensitivity of the MRL/MpJ mouse to the neuroplastic and behavioral effects of chronic antidepressant treatments. Neuropsychopharmacology 34:1764-1773.

Blatow M, Caputi A, Burnashev N, Monyer H, Rozov A (2003) Ca2 + buffer saturation underlies paired pulse facilitation in calbindin-D28kcontaining terminals. Neuron 38:79-88.

Brandt MD, Jessberger S, Steiner B, Kronenberg G, Reuter K, Bick-Sander A, von der Behrens W, Kempermann G (2003) Transient calretinin expression defines early postmitotic step of neuronal differentiation in adult hippocampal neurogenesis of mice. Mol Cell Neurosci 24:603-613. 
Brown JP, Couillard-Després S, Cooper-Kuhn CM, Winkler J, Aigner L, Kuhn HG (2003) Transient expression of doublecortin during adult neurogenesis. J Comp Neurol 467:1-10.

Bruel-Jungerman E, Laroche S, Rampon C (2005) New neurons in the dentate gyrus are involved in the expression of enhanced long-term memory following environmental enrichment. Eur J Neurosci 21:513-521.

Bruel-Jungerman E, Davis S, Rampon C, Laroche S (2006) Long-term potentiation enhances neurogenesis in the adult dentate gyrus. J Neurosci 26:5888-5893.

Caldji C, Diorio J, Anisman H, Meaney MJ (2004) Maternal behavior regulates benzodiazepine/GABAA receptor subunit expression in brain regions associated with fear in BALB/c and C57BL/6 mice. Neuropsychopharmacology 29:1344-1352.

Cameron HA, McKay RD (2001) Adult neurogenesis produces a large pool of new granule cells in the dentate gyrus. J Comp Neurol 435:406-417.

Cameron HA, Woolley CS, McEwen BS, Gould E (1993) Differentiation of newly born neurons and glia in the dentate gyrus of the adult rat. Neuroscience 56:337-344.

Clark PJ, Brzezinska WJ, Thomas MW, Ryzhenko NA, Toshkov SA, Rhodes JS (2008) Intact neurogenesis is required for benefits of exercise on spatial memory but not motor performance or contextual fear conditioning in C57BL/6J mice. Neuroscience 155:1048-1058.

Cole AJ, Abu-Shakra S, Saffen DW, Baraban JM, Worley PF (1990) Rapid rise in transcription factor mRNAs in rat brain after electroshock-induced seizures. J Neurochem 55:1920-1927.

Dayer AG, Ford AA, Cleaver KM, Yassaee M, Cameron HA (2003) Shortterm and long-term survival of new neurons in the rat dentate gyrus. J Comp Neurol 460:563-572.

Dayer AG, Cleaver KM, Abouantoun T, Cameron HA (2005) New GABAergic interneurons in the adult neocortex and striatum are generated from different precursors. J Cell Biol 168:415-427.

Dupret D, Revest JM, Koehl M, Ichas F, De Giorgi F, Costet P, Abrous DN, Piazza PV (2008) Spatial relational memory requires hippocampal adult neurogenesis. PLoS One 3:e1959.

Eriksson PS, Perfilieva E, Björk-Eriksson T, Alborn AM, Nordborg C, Peterson DA, Gage FH (1998) Neurogenesis in the adult human hippocampus. Nat Med 4:1313-1317.

Espósito MS, Piatti VC, Laplagne DA, Morgenstern NA, Ferrari CC, Pitossi FJ, Schinder AF (2005) Neuronal differentiation in the adult hippocampus recapitulates embryonic development. J Neurosci 25:10074-10086.

Gallagher M, Burwell R, Burchinal M (1993) Severity of spatial learning impairment in aging: development of a learning index for performance in the Morris water maze. Behav Neurosci 107:618-626.

Ge S, Goh EL, Sailor KA, Kitabatake Y, Ming GL, Song H (2006) GABA regulates synaptic integration of newly generated neurons in the adult brain. Nature 439:589-593.

Ge S, Yang CH, Hsu KS, Ming GL, Song H (2007) A critical period for enhanced synaptic plasticity in newly generated neurons of the adult brain. Neuron 54:559-566.

Gerlai R, Clayton NS (1999) Analysing hippocampal function in transgenic mice: an ethological perspective. Trends Neurosci 22:47-51.

Gould E, Vail N, Wagers M, Gross CG (2001) Adult-generated hippocampal and neocortical neurons in macaques have a transient existence. Proc Natl Acad Sci U S A 98:10910-10917.

Imayoshi I, Sakamoto M, Ohtsuka T, Takao K, Miyakawa T, Yamaguchi M, Mori K, Ikeda T, Itohara S, Kageyama R (2008) Roles of continuous neurogenesis in the structural and functional integrity of the adult forebrain. Nat Neurosci 11:1153-1161.

Jaholkowski P, Kiryk A, Jedynak P, Ben Abdallah NM, Knapska E, Kowalczyk A, Piechal A, Blecharz-Klin K, Figiel I, Lioudyno V, Widy-Tyszkiewicz E, Wilczynski GM, Lipp HP, Kaczmarek L, Filipkowski RK (2009) New hippocampal neurons are not obligatory for memory formation; cyclin D2 knockout mice with no adult brain neurogenesis show learning. Learn Mem 16:439-451.

Jessberger S, Kempermann G (2003) Adult-born hippocampal neurons mature into activity-dependent responsiveness. Eur J Neurosci 18:27072712.

Karten YJ, Jones MA, Jeurling SI, Cameron HA (2006) GABAergic signaling in young granule cells in the adult rat and mouse dentate gyrus. Hippocampus 16:312-320.

Kee N, Teixeira CM, Wang AH, Frankland PW (2007) Preferential incorpo- ration of adult-generated granule cells into spatial memory networks in the dentate gyrus. Nat Neurosci 10:355-362.

Kempermann G, Gage FH (2002) Genetic influence on phenotypic differentiation in adult hippocampal neurogenesis. Brain Res Dev Brain Res 134:1-12.

Kempermann G, Kuhn HG, Gage FH (1997a) Genetic influence on neurogenesis in the dentate gyrus of adult mice. Proc Natl Acad Sci U S A 94:10409-10414.

Kempermann G, Kuhn HG, Gage FH (1997b) More hippocampal neurons in adult mice living in an enriched environment. Nature 386:493-495.

Kempermann G, Gast D, Kronenberg G, Yamaguchi M, Gage FH (2003) Early determination and long-term persistence of adult-generated new neurons in the hippocampus of mice. Development 130:391-399.

Kerjan G, Koizumi H, Han EB, Dubé CM, Djakovic SN, Patrick GN, Baram TZ, Heinemann SF, Gleeson JG (2009) Mice lacking doublecortin and doublecortin-like kinase 2 display altered hippocampal neuronal maturation and spontaneous seizures. Proc Natl Acad Sci U S A 106:67666771.

Kim JS, Jung J, Lee HJ, Kim JC, Wang H, Kim SH, Shin T, Moon C (2009a) Differences in immunoreactivities of Ki-67 and doublecortin in the adult hippocampus in three strains of mice. Acta Histochem 111:150-156.

Kim KK, Adelstein RS, Kawamoto S (2009b) Identification of neuronal nuclei (NeuN) as Fox-3, a new member of the Fox-1 gene family of splicing factors. J Biol Chem. Advance online publication. Retrieved Sept. 7, 2009. doi:10.1074/jbc.M109.052969.

Leuner B, Mendolia-Loffredo S, Kozorovitskiy Y, Samburg D, Gould E, Shors TJ (2004) Learning enhances the survival of new neurons beyond the time when the hippocampus is required for memory. J Neurosci 24:7477-7481.

Madsen TM, Kristjansen PE, Bolwig TG, Wörtwein G (2003) Arrested neuronal proliferation and impaired hippocampal function following fractionated brain irradiation in the adult rat. Neuroscience 119:635-642.

Malberg JE, Eisch AJ, Nestler EJ, Duman RS (2000) Chronic antidepressant treatment increases neurogenesis in adult rat hippocampus. J Neurosci 20:9104-9110.

Mandyam CD, Harburg GC, Eisch AJ (2007) Determination of key aspects of precursor cell proliferation, cell cycle length and kinetics in the adult mouse subgranular zone. Neuroscience 146:108-122.

Mirescu C, Gould E (2006) Stress and adult neurogenesis. Hippocampus 16:233-238.

Pollak DD, Monje FJ, Zuckerman L, Denny CA, Drew MR, Kandel ER (2008) An animal model of a behavioral intervention for depression. Neuron 60:149-161.

Racine RJ (1972) Modification of seizure activity by electrical stimulation. II. Motor seizure. Electroencephalogr Clin Neurophysiol 32:281-294.

Ray J, Gage FH (2006) Differential properties of adult rat and mouse brainderived neural stem/progenitor cells. Mol Cell Neurosci 31:560-573.

Sahay A, Hen R (2007) Adult hippocampal neurogenesis in depression. Nat Neurosci 10:1110-1115.

Saxe MD, Battaglia F, Wang JW, Malleret G, David DJ, Monckton JE, Garcia AD, Sofroniew MV, Kandel ER, Santarelli L, Hen R, Drew MR (2006) Ablation of hippocampal neurogenesis impairs contextual fear conditioning and synaptic plasticity in the dentate gyrus. Proc Natl Acad Sci U S A 103:17501-17506.

Saxe MD, Malleret G, Vronskaya S, Mendez I, Garcia AD, Sofroniew MV, Kandel ER, Hen R (2007) Paradoxical influence of hippocampal neurogenesis on working memory. Proc Natl Acad Sci U S A 104:4642-4646.

Schlessinger AR, Cowan WM, Gottlieb DI (1975) An autoradiographic study of the time of origin and the pattern of granule cell migration in the dentate gyrus of the rat. J Comp Neurol 159:149-175.

Schmidt-Hieber C, Jonas P, Bischofberger J (2004) Enhanced synaptic plasticity in newly generated granule cells of the adult hippocampus. Nature 429:184-187.

Shors TJ, Miesegaes G, Beylin A, Zhao M, Rydel T, Gould E (2001) Neurogenesis in the adult is involved in the formation of trace memories. Nature 410:372-376

Shors TJ, Townsend DA, Zhao M, Kozorovitskiy Y, Gould E (2002) Neurogenesis may relate to some but not all types of hippocampal-dependent learning. Hippocampus 12:578-584.

Snyder JS, Kee N, Wojtowicz JM (2001) Effects of adult neurogenesis on synaptic plasticity in the rat dentate gyrus. J Neurophysiol 85:2423-2431. 
Snyder JS, Hong NS, McDonald RJ, Wojtowicz JM (2005) A role for adult neurogenesis in spatial long-term memory. Neuroscience 130:843-852.

Snyder JS, Radik R, Wojtowicz JM, Cameron HA (2009a) Anatomical gradients of adult neurogenesis and activity: young neurons in the ventral dentate gyrus are activated by water maze training. Hippocampus 19:360-370.

Snyder JS, Glover LR, Sanzone KM, Kamhi JF, Cameron HA (2009b) The effects of exercise and stress on the survival and maturation of adultgenerated granule cells. Hippocampus 19:898-906.

Tint I, Jean D, Baas PW, Black MM (2009) Doublecortin associates with microtubules preferentially in regions of the axon displaying actin-rich protrusive structures. J Neurosci 29:10995-11010.

Toni N, Teng EM, Bushong EA, Aimone JB, Zhao C, Consiglio A, van Praag H, Martone ME, Ellisman MH, Gage FH (2007) Synapse formation on neurons born in the adult hippocampus. Nat Neurosci 10:727-734.

van Praag H, Schinder AF, Christie BR, Toni N, Palmer TD, Gage FH (2002) Functional neurogenesis in the adult hippocampus. Nature 415 1030-1034.

West MJ, Andersen AH (1980) An allometric study of the area dentata in the rat and mouse. Brain Res 2:317-348.
Whishaw IQ, Metz GA, Kolb B, Pellis SM (2001) Accelerated nervous system development contributes to behavioral efficiency in the laboratory mouse: a behavioral review and theoretical proposal. Dev Psychobiol 39:151-170.

Winocur G, Wojtowicz JM, Sekeres M, Snyder JS, Wang S (2006) Inhibition of neurogenesis interferes with hippocampus-dependent memory function. Hippocampus 16:296-304.

Wojtowicz JM, Askew ML, Winocur G (2008) The effects of running and of inhibiting adult neurogenesis on learning and memory in rats. Eur J Neurosci 27:1494-1502.

Zaharia MD, Kulczycki J, Shanks N, Meaney MJ, Anisman H (1996) The effects of early postnatal stimulation on Morris water-maze acquisition in adult mice: genetic and maternal factors. Psychopharmacology 128: 227-239.

Zhang CL, Zou Y, He W, Gage FH, Evans RM (2008) A role for adult TLXpositive neural stem cells in learning and behaviour. Nature 451: 1004-1007.

Zhao C, Teng EM, Summers RG Jr, Ming GL, Gage FH (2006) Distinct morphological stages of dentate granule neuron maturation in the adult mouse hippocampus. J Neurosci 26:3-11. 